\title{
AUDIENCE CENTERED PADA METODE PRESENTASI SEBAGAI AKTUALISASI \\ PENDEKATAN STUDENT CENTERED LEARNING
}

\author{
Dliyaul Millah \\ UIN Walisongo Semarang, Jawa Tengah, Indonesia \\ dhea_elmeela@yahoo.com
}

\begin{abstract}
Abstrak
Penulisan artikel ini dilatarbelakangi oleh adanya perubahan paradigma dari guru sebagai pusat dalam pembelajaran/ Teacher Centered Learning (TCL) kepada siswa sebagai pusat dalam pembelajaran/Student Centered Learning (SCL). Untuk maksud tersebut, penulis melakukan penelitian kualitatif dengan memfokuskan pada metode presentasi sebagai salah satu metode yang dapat diaplikasikan untuk mengaktualisasikan Student Centered Learning (SCL) dalam proses pembelajaran di dalam kelas. Metode ini dapat diterapkan pada fokus menempatkan audiens sebagai komponen penting dalam keberhasilan pembelajaran aktif. Peran guru di sini adalah hanya sebagai seorang hakim super yang memungkinkan presenter untuk menangani kegiatan kelas dan menerapkan beberapa teknik untuk membuat para audien aktif dan interaktif.
\end{abstract}

Kata kunci: Student Centered Learning (SCL), presentasi, audiens sebagai pusat pembelajaran

\section{Abstract}

AUDIENCE CENTERED ON THE METHOD OF PRESENTATION AS THE ACTUALIZATION OF STUDENT LEARNING CENTERED APPROACH. The writing of this article was based on the changing of the paradigm from Teacher Centered 
Learning (TCL) to Student Centered Learning (SCL). For that purpose, the author did a qualitative research by focusing on the presentation method as one of methods that can be apply to actualize the SCL in the learning process in classroom. This method could be applied on the focus of audience centered that places the audience as the important component in the success of an active learning. The role of the teacher here is only as a super judge who lets the presenters to handle the classroom activities and apply some techniques to make their audience be active and interactive.

Keywords: Student Centered Learning (SCL), presentation, audience centered

\section{A. Pendahuluan}

Pendidikan merupakan kebutuhan primer dalam masyarakat, karena pendidikan bermanfaat untuk kelangsungan dan kemajuan hidup manusia. Manusia dapat mentransfer ilmu pengetahuan, nilainilai, ketrampilan, serta teknologi antar generasi melalui pendidikan. Pendidikan pula yang menjamin keberlangsungan kebudayaan dan peradaban manusia di bumi ini. Pendidikan menurut Undangundang No. 20 Tahun 2003 tentang Sistem Pendidikan Nasional (SISDIKNAS) adalah usaha sadar dan terencana untuk mewujudkan suasana belajar dan proses pembelajaran agar peserta didik secara aktif mengembangkan potensi dirinya untuk memiliki kekuatan spritual keagamaan, pengendalian diri, kepribadian, kecerdasan, akhlak mulia, serta keterampilan yang diperlukan dirinya, masyarakat, bangsa, dan negara.

Pemerintah mengeluarkan Undang-undang No. 20 Tahun 2003 tentang Sistem Pendidikan Nasional yang menyatakan bahwa: Pendidikan Nasional berfungsi mengembangkan kemampuan dan membentuk serta peradaban bangsa yang bermanfaat dalam rangka mencerdaskan kehidupan bangsa bertujuan untuk berkembangnya potensi peserta didik agar menjadi manusia beriman dan bertaqwa kepada Tuhan Yang Maha Esa, berakhlak mulia, sehat, berilmu, cakap, kreatif, mandiri dan menjadi warga negara yang demokratis serta bertanggung jawab (Hamalik, 2009: 131-132).

Tujuan pendidikan di atas diwujudkan melalui proses pendidikan. Oleh karena itu pendidikan memegang peranan penting 
dalam mengembangkan potensi yang telah dimiliki oleh manusia dan pendidikan merupakan wahana mendapatkan ilmu pengetahuan. Tujuan pendidikan dapat menjadikan peserta didik beriman dan bertaqwa kepada Tuhan Yang Maha Esa serta menjadi diri yang bertanggung jawab, setiap pendidikan akan membekali peserta didik dengan ilmu untuk masa depan yang diarahkan untuk meningkatkan kualitas manusia melalui olah batin (aspek transendensi), olah pikir (aspek kognisi), olah rasa (aspek afeksi), dan olah kinerja (aspek psikomotoris) agar memiliki daya saing dalam menghadapi tantangan global. Jadi, secara garis besar pendidikan dapat dimaknai dalam arti luas dan sempit, secara luas pendidikan adalah bagian dari kehidupan itu sendiri dan berlangsung sepanjang hayat, sedangkan pendidikan dalam arti sempit dimaknai sebagai pengajaran yang diselenggarakan di sekolah.

Sekolah sebagai sebuah satuan pendidikan sebaiknya dijadikan sebagai tempat untuk mencari, mengembangkan dan membekali peserta didik dengan berbagai kompetensi dengan tujuan agar peserta didik dapat menyesuaikan dirinya dengan perubahan yang ada. Sejalan dengan tujuan tersebut, maka proses belajar mengajar di sekolah diharapkan dapat menjadikan peserta didik lebih berpartisipasi dan berperan lebih aktif, dimana hal ini dapat memberikan mereka pengalaman belajar sesungguhnya yang sesuai dengan konsep-konsep dan prinsip-prinsip pendidikan itu sendiri serta dapat tercapainya hasil belajar yang optimal.

Di Indonesia, pelaksanaan pembelajaran di sekolah lebih banyak menggunakan metode konvensional yang mengakibatkan peserta didik kurang terlibat secara aktif dalam kegiatan pembelajaran. Peseta didik cenderung hanya mendengar dan menerima penjelasan dari guru tanpa diberi kesempatan untuk mengutarakan pendapatnya secara luas dan terbuka. Kondisi seperti ini dapat dikatakan tidak memberdayakan kemauan dan kemampuan peserta didik dalam berbuat untuk memperkaya belajarnya (learning to do) dengan meningkatkan interaksi dengan lingkungannya. Sehingga tidak akan bisa membangun pemahaman dan pengetahuan terhadap dunia sekitarnya (learning to know). Lebih jauh lagi mereka pun tidak memiliki kesempatan untuk membangun pengetahuan dan kepercayaan dirinya (learning to be), maupun kemampuan 
berinteraksi dengan berbagai individu atau kelompok yang beragam (learning to live together) di masyarakat.

Sehubungan dengan hal di atas guru dapat mengembangkan model pembelajaran yang mampu meningkatkan kompetensi peserta didik. Belajar akan lebih bermakna (meaningful learning) jika peserta didik mengalami apa yang dipelajarinya, bukan saja mengetahuinya. Pembelajaran yang berorientasi target penguasaan materi terbukti berhasil dalam kompetensi mengingat dalam jangka pendek, tetapi gagal dalam membekali peserta didik memecahkan masalah dalam kehidupan jangka panjang. Pendekatan pembelajaran yang konvensional seperti ini biasa disebut dengan Teacher Centered Learning.

Dalam perkembangannya pendekatan Teacher Centered Learning (TCL) tidak lagi sesuai dengan yang terjadi pada kehidupan nyata. TCL merupakan pendekatan yang dinilai memandang semua peserta didik sama, padahal setiap individu memiliki kemampuan berbeda-beda. Sistem pendidikan yang ada pada umumnya membatasi setiap gerak ruang peserta didik. Mereka cukup menerima semua ilmu pemberian guru saja, karena guru merupakan sumber pengetahuan. Untuk beberapa kondisi kegiatan TCL memang sudah cukup baik, akan tetapi ketika berhadapan dengan kondisi peserta didik yang memiliki beragam karakter yang berbeda-beda maka paradigma ini sudah tidak bijak diterapkan lagi. Guru dituntut dapat memilih model pembelajaran yang dapat memacu semangat setiap peserta didik untuk secara aktif ikut terlibat dalam pengalaman belajaranya.

Proses pembelajaran yang terjadi seharusnya menggunakan pendekatan konstruksivisme, dimana proses belajar menekankan bahwa peserta didik dalam proses pembelajaran harus bersikap aktif membangun pengetahuan secara individu, bukan hanya menerima begitu saja pengetahuan yang didapatkan. Pengetahuan yang ada dalam diri manusia merupakan konstruksi (bentukan) dari diri kita sendiri, dibentuk ketika individu melakukan interaksi dengan lingkungannya. Teori pembelajaran konstruksivisme didukung oleh Piaget yang melalui teori perkembangan kognitif yang berpendapat bahwa pengetahuan tidak boleh diperoleh secara pasif akan tetapi harus secara aktif melalui tindakan (Trianto, 2009: 29). 
Perubahan paradigma dalam proses pembelajaran yang tadinya berpusat pada guru (Teacher Centered) menjadi pembelajaran yang berpusat pada peserta didik (Student Centered) diharapkan dapat mendorong peserta didik untuk terlibat secara aktif dalam membangun pengetahuan, sikap dan perilaku. Melalui proses pembelajaran dengan keterlibatan peserta didik ini berarti guru tidak mengambil hak anak untuk belajar dalam arti yang sesungguhnya. Dalam proses pembelajaran yang berpusat pada peserta didik, maka peserta didik memperoleh kesempatan dan fasilitasi untuk membangun sendiri pengetahuannya sehingga mereka akan memperoleh pemahaman yang mendalam (deep learning), dan pada akhirnya dapat meningkatkan kualitas peserta didik. Salah satu pendekatan pembelajaran yang tepat untuk dapat mendukung kualitas peserta didik adalah model pembelajaran Student Centered Learning (SCL).

\section{B. Pembahasan}

\section{Pendekatan Student Centered Learning}

Di Indonesia Student Centered Learning (SCL) masih menjadi topik yang populer pada saat ini terutama dikalangan akademisi dan praktisi pendidikan yang ditandai dengan muncul dan ramainya permintaan diskusi, ceramah, dan pelatihan tentang SCL. Pemikir seperti John Dewey, Jean Piaget, dan Vygostky yang karyanya terfokus pada bagaimana peserta didik belajar, bertanggung jawab atas gerak perubahan cara pembelajaran dari yang terpusat pada guru menjadi terpusat pada peserta didik, yaitu Student Centered Learning (SCL). SCL berarti menempatkan peserta didik sebagai pusat dari kegiatan belajar.

Melaksanakan model SCL berarti guru perlu membantu peserta didik untuk menentukan tujuan yang dicapai, mendorong mereka untuk dapat menilai hasil belajarnya sendiri, membantu mereka untuk bekerja sama dalam kelompok, dan memastikan agar mereka mengetahui bagaimana memanfaatkan semua sumber belajar yang tersedia.

Berikut ini beberapa pengertian Student Centered Learning (SCL) yaitu: 
1. Menurut Harsono yang dikutip dalam Kurdi (2009: 110) SCL merupakan pendekatan dalam pembelajaran yang memfasilitasi pembelajar untuk terlibat dalam proses Experiential Learning (pengalaman belajar).

2. Menurut Rogers (1983) yang dikutip dalam Trinova (2013: 327), SCL merupakan hasil dari transisi perpidahan kekuatan dalam proses pembelajaran, dari kekuatan guru sebagai pakar menjadi kekuatan peserta didik sebagai pembelajar. Perubahan ini terjadi setelah banyak harapan untuk memodifikasi atmosfer pembelajaran yang menyebabkan peserta didik menjadi pasif, bosan dan resisten.

3. Menurut Kember (1997) yang dikutip dalam Trinova (2013: 327), SCL merupakan sebuah kutub proses pembelajaran yang menekankan peserta didik sebagai pembangun pengetahuan sedangkan kutub yang lain adalah guru sebagai agen yang memberikan pengetahuan.

4. Menurut Harden dan Crosby (2000) yang dikutip dalam Trinova (2013: 327), SCL menekankan pada peserta didik sebagai pembelajar dan apa yang dilakukan peserta didik untuk sukses dalam belajar dibanding dengan apa yang dilakukan oleh guru.

Dari berbagai definisi tersebut dapat dipahami bahwa Student Centered Learning (SCL) adalah suatu model pembelajaran yang menempatkan peserta didik sebagai pusat dari proses belajar. Dalam pendekatan pembelajaran SCL, guru harus mampu melaksanakan perannya dengan baik yaitu tidak hanya sebagai pengajar, tetapi juga sebagai motivator, fasilitator, dan inovator. Guru tidak hanya dituntut untuk mengajar saja di depan kelas melainkan juga berperan membantu peserta didik untuk memecahkan masalah saat mereka mengalami kesulitan dalam proses pembelajaran. Natawijaya dalam Depdiknas (2000: 31) menyebutkan bahwa belajar aktif adalah suatu sistem belajar mengajar yang menekankan keaktifan peserta didik secara fisik, mental, intelektual dan emosional guna memperoleh hasil belajar berupa perpaduan antara aspek kognitif, afektif dan psikomotor.

Dalam menerapkan konsep SCL, peserta didik diharapkan sebagai peserta aktif dan mandiri dalam proses belajarnya, yang 
bertanggung jawab dan berinisiatif untuk mengenali kebutuhan belajarnya, menemukan sumber-sumber informasi untuk dapat menjawab kebutuhannya, membangun serta mempresentasikan pengetahuannya berdasarkan kebutuhan serta sumber-sumber yang ditemukannya. Dalam batas-batas tertentu peserta didik dapat memilih sendiri apa yang akan dipelajarinya.

Pembelajaran yang berpusat pada peserta didik adalah proses belajar mengajar berdasarkan kebutuhan dan minat peserta didik. Model pembelajaran yang berpusat pada peserta didik dirancang untuk menyediakan sistem belajar yang fleksibel sesuai dengan kehidupan dan gaya belajar peserta didik. Lembaga pendidikan dan guru tidak berperan sebagai sentral melainkan hanya sebagai penunjang (Hamalik, 2004: 201).

SCL adalah tentang bagaimana cara membantu peserta didik menemukan gaya belajarnya sendiri, memahami motivasi dan menguasai keterampilan belajar yang paling sesuai bagi mereka. Dalam melaksanakan metode pembelajaran, seorang pendidik perlu membantu peserta didik untuk menentukan tujuan yang dapat dicapai, mendorong mereka untuk dapat menilai hasil belajarnya sendiri, membantu mereka untuk bekerja sama dalam kelompok, dan memastikan agar mereka mengetahui bagaimana memanfaatkan semua sumber belajar yang tersedia. Pembelajaran lebih merupakan bentuk pengembangan diri secara keseluruhan dibandingkan kemajuan linier yang dicapai guru dengan cara pujian dan sanksi. SCL, yang menekankan pada minat, kebutuhan dan kemampuan individu, menjanjikan model belajar yang menggali motivasi intrinsik untuk membangun masyarakat yang suka dan selalu belajar. Model belajar ini sekaligus dapat mengembangkan kualitas sumber daya manusia yang dibutuhkan masyarakat seperti kreativitas, kepemimpinan, rasa percaya diri, kemandirian, kedisiplinan, kekritisan dalam berpikir, kemampuan berkomunikasi dan bekerja dalam tim, keahlian teknis, serta wawasan global untuk dapat selalu beradaptasi terhadap perubahan dan perkembangan.

Dengan inovasi ini akan terjadi perubahan peran peserta didik dalam proses pembelajaran sebagai berikut:

1. Peserta didik ikut bertanggungjawab dalam proses pembelajaran. 
2. Peserta didik belajar bagaimana belajar secara mandiri.

3. Peserta didiksecara aktif mencari pengetahuan dan melakukan konstruksi dan pemahaman terhadap materi pembelajaran. Sedangkan guru akan berperan dalam:

1. Menyediakan berbagai cara dan bentuk untuk mengakses bahan pembelajaran.

2. Bertindak sebagai fasilitator yang membantu peserta didik dalam mengkases dan memproses bahan pembelajaran.

3. Memfasilitasi proses belajar aktif.

4. Memberikan dukungan kepada peserta didik dalam belajar aktif untuk meningkatkan kemampuan siswa dalam menguasai pengetahuan.

5. Meningkatkan motivasi dan semangat peserta didik untuk memajukan pelajaran dan meningkatkan kemampuannya untuk belajar secara mandiri.

SCL merupakan pembelajaran dengan menggunakan sepasang perspektif, yaitu fokus pada individu pembelajar (keturunan, pengalaman, perspektif, latar belakang, bakat, minat, kapasitas, dan kebutuhan) dengan fokus pada pembelajaran (pengetahuan yang paling baik tentang pembelajaran dan bagaimana hal itu timbul serta tentang praktek pengajaran yang paling efektif dalam meningkatkan tingkat motivasi, pembelajaran, dan prestasi bagi semua pembelajar.

SCL dalam penerapannya dapat memudahkan perancangan instruksi pembelajaran yang efektif untuk setiap peserta didik, memudahkan penyerapan materi bagi mereka serta dapat meningkatkan kemandirian maupun kemampuan komunikasi dan kolaborasi bagi mereka, dengan demikian model pembelajaran SCL adalah kunci keberhasilan dalam penerapan suatu proses pembelajaran yang dilaksanakan oleh lembaga pendidikan terkhusus oleh para pendidik (guru).

\section{Karakteristik Pembelajaran Berbasis Student Centered Learning}

Beberapa karakteristik model pembelajaran berbasis Student Centered Learning (SCL) menurut Wina Sanjaya, yaitu:

1. Mengajar berpusat pada peserta didik bukan pada guru

2. Proses pembelajaran berlangsung dimana saja

3. Pembelajaran berorientasi pada pencapaian tujuan 
4. Suasana berpusat pada peserta didik

5. Peserta didik yang mengendalikan proses

6. Peserta didik yang bertanggung jawab

7. Pembelajaran bersifat kooperatif, kolaboratif, atau independen. Peserta didik harus saling bekerja sama. Peserta didik berkompetisi dengan kinerja mereka sebelumnya (Sanjaya, 2007: 97-98).

Karakteristik dari pembelajaran berbasis SCL yang menyangkut aspek dari pengajar, peserta didik, materi dan teknik penyampainnya secara terperinci dapat digambarkan sebagai berikut:

1. Pengajar berperan sebagai penunjang, dalam hal ini bertugas sebagai perantara pembelajaran yang membantu mengarahkan peserta didik, dan apabila perlu ikut dalam membantu peserta didik dalam mengembangkan materi yang ada.

2. Pengajar berwawasan luas dan bersifat terbuka terhadap masukan maupun kritikan yang membangun bagi peserta didik.

3. Pengajar menggunakan cara penyampaian materi yang dianggap sesuai dengan kebutuhan dan kondisi peserta didik, dalam hal ini tidak menutup kemungkinan seorang pengajar menggunakan cara pengajaran yang berbeda untuk setiap kelas.

4. Peserta didik merupakan tokoh utama pembela- jaran yang memiliki wewenang untuk menentukan apa saja yang akan dipelajari terkait dengan materi yang ada termasuk cara penyampaiannya.

5. Peserta didik merupakan tokoh yang aktif pada proses pembelajaran yang senantiasa memberikan gagasan, baik saran dan kritik. Mereka bukan hanya menerima materi dari pengajar melainkan juga ikut serta dalam merumuskan, mengembangkan dan memproses materi pembelajaran.

6. Peserta didik mampu untuk mengembangkan materi belajar secara mandiri, dimana saja, kapan saja, bukan hanya di kelas atau di tempat pengajar berada.

7. Peserta didik mampu merumuskan harapan mereka terhadap proses pembelajaran dan mengukur kinerja mereka sendiri. 
8. Peserta didik saling berkolaborasi satu sama lain.

9. Peserta didik memantau pembelajarannya sendiri, sehingga mampu untuk merumuskan strategi pembelajaran yang tepat untuk mencapai hasil yang optimal.

10. Peserta didik termotivasi untuk mencapai sasaran yang telah ditetapkannya sendiri.

11. Peserta didik memilih anggota kelompoknya sendiri dan menemukan bagaimana cara bekerja dalam kelompok tersebut.

12. Materi pembelajaran bersifat sebagai arahan bukan patokan pembelajaran, sehingga pengajar dan peserta didik tidak hanya terpaku pada materi yang ada, namun kreatif untuk mengembangkannya secara berkelanjutan.

13. Pembelajaran adalah proses pencarian ilmu pengetahuan secara aktif atau proses perumusan ilmu bukan proses penangkapan ilmu semata.

14. Peserta didik membangun pengetahuannya sendiri melalui proses pembelajaran pribadi yang dilaluinya. Hubungan timbal balik antara peserta didik dengan komponenkomponen lain penyusun proses pembelajaran yang tercipta pada beberapa aktivitas, seperti skilled instructor, online curiculum, online asessment, communities, optimal textbook, projek and case studies, instruction multimedia, simulation, remote lab, hand-on skill exams, hand-on lab.

15. Menempatkan peserta didik sebagai subjek belajar, artinya peserta didik berperan aktif dalam setiap proses pembelajaran dengan cara menemukan dan menggali sendiri materi pelajaran.

16. Peserta didik yang mendominasi pembelajaran, sedangkan guru hanya sebagai fasilitator (mitra pembelajaran).

17. Peserta didik belajar melalui kegiatan kelompok, seperti kegiatan kelompok, berdiskusi, saling menerima dan memberi.

18. Tujuan akhir dari proses pembelajran adalah kepuasan diri.

19. Peserta didik ikut bertanggung jawab dalam proses pembelajaran.Siswa belajar bagaimana belajar secara mandiri. 
20. Peserta didik secara aktif mencari pengetahuan dan melakukan konstruksi dan pemahaman terhadap materi pembelajaran.

\section{Karaktersitik Media Pembelajaran Sebagai Pendukung Pendekatan Student Centered Learning}

Untuk mendukung proses integrasi antara sebuah pendekatan pembelajaran dan metode pembelajaran, maka menurut Syamsul (2010: diambil dari http://old.its.ac.id/berita.php?nomer=6418) manajemen sekolah, guru dan peserta didik harus memahami 9 (sembilan) karaktersitik metode pembelajaran sebagai pendukung metode SCL, antara lain:

1. Aktif. Memungkinkan peserta didik dapat terlibat aktif oleh adanya proses belajar yang menarik dan bermakna.

2. Konstruktif. Memungkinkan peserta didik dapat menggabungkan ide-ide baru kedalam pengetahuan yang telah dimiliki sebelumnya untuk memahami makna atau keinginan tahuan dan keraguan yang selama ini ada dalam benaknya.

3. Kolaboratif. Memungkinkan peserta didik dalam suatu kelompok atau komunitas yang saling bekerjasama, berbagi ide, saran atau pengalaman, menasehati dan memberi masukan untuk sesama anggota kelompoknya.

4. Antusiastik. Memungkinkan peserta didik dapat secara aktif dan antusias berusaha untuk mencapai tujuan yang diinginkan.

5. Dialogis. Memungkinkan proses belajar secara inherent merupakan suatu proses sosial dan dialogis dimana peserta didik memperoleh keuntungan dari proses komunikasi tersebut baik di dalam maupun luar sekolah.

6. Kontekstual. Memungkinkan situasi belajar diarahkan pada proses belajar yang bermakna (real-world) melalui pendekatan "problem-based atau case-based learning".

7. Reflektif. Memungkinkan peserta didik dapat menyadari apa yang telah ia pelajari serta merenungkan apa yang telah dipelajarinya sebagai bagian dari proses belajar itu sendiri.

8. Multisensory. Memungkinkan pembelajaran dapat disampaikan untuk berbagai modalitas belajar (multisensory) 
baik audio, visual, maupun kinestetik.

9. High Order Thinking Skills Training. Memungkinkan untuk melatih kemampuan berpikir tingkat tinggi (seperti problem solving, pengambilan keputusan, dan lain-lain).

Kegiatan pembelajaran pada model SCL adalah peserta didik yang mendominasi kegiatan pembelajaran, dalam hal ini peserta didik yang lebih aktif dalam melakukan proses pembelajaran sedangkan guru hanya sebagai fasilitator, peserta didik ditempatkan sebagai subjek belajar yang berperan dalam menemukan dan menggali sendiri materi pelajaran. Tujuan akhir kegiatan pembelajaran SCL adalah mengharapkan kepuasan diri. Tujuan yang ingin dicapai adalah seluruh aspek perkembangan peserta didik, dengan demikian keberhasilan pembelajaran diukur melalui berbagai cara, misalnya dengan evaluasi proses, hasil karya peserta didik, penampilan, rekaman, observasi, wawancara, dan lain-lain. Kemudian mendorong peserta didik untuk terlibat secara aktif dalam membangun pengetahuan, sikap dan perilaku. Oleh karena itu, metode presentasi dianggap sebagai metode yang mampu mengaktualisasikan penerapan pendekatan SCL.

\section{Metode Presentasi}

Bowman (1998: 1) menyebutkan bahwa "A presentation is the practice of showing and explaining the content of a topic to an audience or learner". Metode presentasi adalah metode pengungkapan ide, gagasan, perasaan di depan umum oleh satu atau lebih presenter dengan menyertakan naskah makalah atau tidak. Bagi kebanyakan orang metode presentasi menuntut adanya pembuatan ringkasan dari sekian masalah atau konsep yang akan dipaparkannya. Tujuannya adalah melatih peserta didik mengembangkan keaktifan dan kemampuan berfikir serta cara berfikir kritis dan analitis.

Manfaat yang akan diraih dari metode presentasi adalah adanya suasana kelas yang hidup. Secara psikologis peserta didik merasa bangga bisa mengungkapkan ide, perasaan dan pikirannya dan tampil paling tidak di depan teman-teman sekelas dan gurunya. Rasa bangga itu akan lebih kentara jika kita mendokumentasikannya, dan di akhir program sambil membagikan hasil evaluasi. Kemampuan menulis materi atau ide akan menjadi pengalaman yang menarik bagi 
para peserta didik untuk bekal nanti melanjutkan pendidikan ke jenjang yang lebih tinggi. Manfaat yang lain yakni melatih berfikir kritis dan analitis. Kadang-kadang muncul hal yang bagi penulis tidak pernah terfikirkan bahwa ada sebuah fakta atau data di depan kita. Mereka mampu menangkap dan menggalinya.

\section{Audience Centered pada Metode Presentasi}

Audience Centered pada metode presentasi merupakan salah satu media dalam mengaplikasikan pendekatan Student Centered Learning (SCL). Audience Centered pada metode presentasi dipercaya sangat efektif dalam meningkatkan proses pembelajaran guna meraih hasil belajar mahasiswa secara optimal. Ini sesuai dengan filosofi belajar, bahwa belajar merupakan kegiatan memperoleh pengetahuan baru dimana semakin banyak pengetahuan didapat mahasiswa, semakin besar peluang mereka untuk terus meningkatkan kualitas sikap dan prilakunya. Pandangan ini sejalan dengan pendekatan belajar yang dikembangkan aliran psikologi kognitif yang meyakini bahwa para mahasiswa yang memiliki informasi pengetahuan sangat banyak dapat melakukan eksplorasi terhadap sumber-sumber belajar baru, baik sendiri maupun bersama-sama dengan peer groupnya. Dengan begitu, mereka bisa memperoleh banyak informasi pengetahuan baru dan terus menambah kesimpulan-kesimpulan baru.

Attard dan tim dari Education International (EI) dan European Students' Union (2010) berpendapat bahwa proses belajar terbaik adalah dengan melibatkan para peserta didik untuk mempelajari materi pelajaran secara aktif. Di saat yang sama, pengajar juga lebih berperan dalam memfasilitasi para peserta didiknya belajar. Beberapa fasilitasi tersebut seperti menugaskan melaksanakan riset, memberi mereka peluang untuk mempresentasikan hasil kajian, berdiskusi dengan peer group, dan belajar menyimpulkan hasil diskusinya. Attard membuat perbandingan capaian hasil belajar tersebut seperti dideskripsikan dalam tabel berikut ini. 


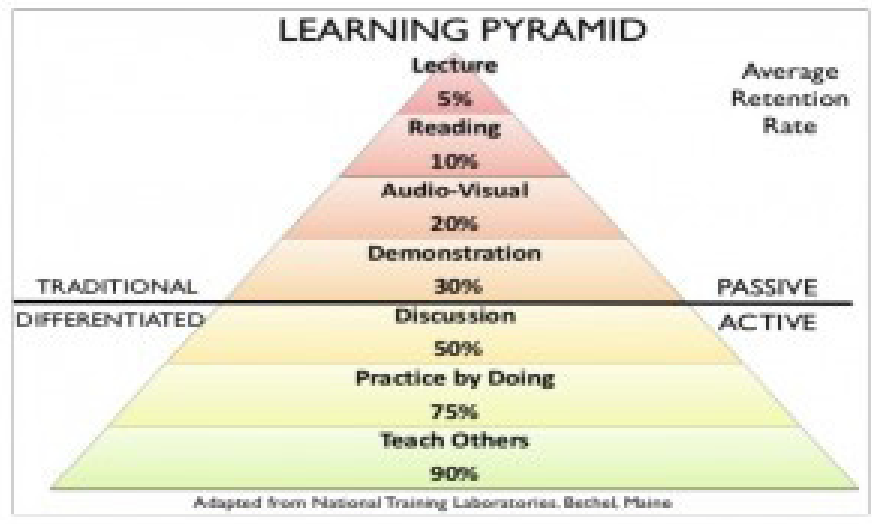

Gambar 1.1: Learning Pyramid

Dalam diagram di atas terlihat bahwa belajar dengan model passive learning melalui ceramah, membaca, audio-visual, dan demonstrasi hanya mampu menghasilkan pencapaian belajar paling tinggi $30 \%$. Bahkan bila hanya mengandalkan audio-visual, membaca, dan kuliah, pencapaian materi pelajaran yang bisa melekat dan diingat mahasiswa masing-masing hanya mencapai 20\%, $10 \%$ dan bahkan 5\%. Prosentase pencapaian demikian jauh berbeda dengan model belajar aktif melalui diskusi, praktik, atau mengajar orang lain. Pencapaian paling rendah dicatatkan metode diskusi $50 \%$. Sedangkan praktek dan mengajar yang lain mencatatkan prosentase hasil belajar lebih tinggi, yakni $75 \%$ dan $90 \%$. Pengajaran metode terakhir dilakukan dengan menjelaskan informasi pengetahuan yang dipelajarinya pada peer group-nya dengan saling bertanya, berdialog, berdiskusi atau bahkan berdebat. Dengan demikian, pembelajaran berbasis audiens atau Audience Centered pada metode presentasi saat ini sangat direkomendasikan agar peserta didik mampu meraih hasil belajar yang maksimal.

Dalam Audience Centered pada metode presentasi ini para peserta didik menjadi pelaku aktif dalam kegiatan belajar. Ini serupa dengan SCL dimana proses pembelajaran berpusat pada peserta didik, akan tetapi dalam audience centered peserta didik diberi kebebasan sepenuhnya untuk berpartisipasi aktif dan menghandle seluruh kegiatan pembelajaran aktif. Dalam hal ini, para 
peserta didik difasilitasi melakukan eksplorasi bahan-bahan ajar dan mendiskusikan berbagai informasi yang didapat, sedangkan para pengajar hanya mendampingi mereka selama proses tersebut, sesekali mendorong mereka melakukan proses pencarian, diskusi, dan penyimpulan atas hasil diskusi mereka. pengajar tidak lagi memegang peranan aktif dalam proses belajar peserta didik tetapi dalam Audience Centered pada metode presentasi ini pengajar menjadi lebih santai dan tidak banyak beraktifitas. Pengajar hanya berperan sebagai fasilitator atau super judge yang memberikan pengarahan dan evaluasi di akhir tatap muka pembelajaran. Sebaliknya, dalam Audience Centered pada metode presentasi peserta didik yang menjadi presenter harus lebih aktif membaca dan belajar bersama para audien mereka. Dalam Audience Centered pada metode presentasi, hubungan antara pengajar dan peserta didik adalah hubungan antara senior learner dengan junior learner.

Terdapat banyak manfaat proses belajar dengan pendekatan Audience Centered pada metode presentasi baik bagi kalangan peserta didik yang menjadi presenter, yang menjadi audien, maupun pengajar. Beberapa manfaat bagi kalangan peserta didik yang menjadi presenter dan khususnya yang menjadi audien, antara lain:

1. Menjadikan para peserta didik sebagai bagian integral dari komunitas akademik. Sebenarnya, peserta didik kini disebut sebagai civitas academica, akan tetapi, seringkali posisi itu tidak terwujud hanya karena pengajar tidak memperlakukan mereka sebagai masyarakat akademik, melainkan objek ceramah pengajar yang sekali waktu diukur tingkat pemahamannya terhadap kandungan ceramah tersebut. Sebagai masyarakat akademik, tentu peserta didik memiliki hak untuk melakukan proses inquiry, proses pencarian dan pengkajian, serta proses pemahaman yang dilakukan oleh mereka sendiri. Melalui Audience Centered pada metode presentasi mereka memiliki kesempatan untuk melakukan penelitian dan mempresentasikannya di hadapan peer group dan pengajar mereka. Selanjutnya, pengajar harus memberi masukkan terhadap hasil penelitian para peserta didiknya. Dengan demikian, para peserta didik benar-benar menjadi masyarakat akademik sebagaimana diidealkan. 
2. Meningkatkan motivasi belajar peserta didik. Hal ini karena Audience Centered pada metode presentasi memperlakukan peserta didik sebagai masyarakat akademik yang harus menguasai teori, mengaplikasikannya, dan terus melakukan kajian dan evaluasi atas teori tersebut. Selain itu, para peserta didik juga dituntut untuk mempresentasikan hasil kajiannya pada peer group dan pengajarnya. Dengan demikian, peserta didik akan termotivasi untuk memperbanyak kegiatan belajar di luar kelas sehingga nantinya menjadi masyarakat pembelajar.

3. Peserta didik menjadi lebih independen dan bertanggung jawab untuk terus belajar. Pembelajaran berbasis pada peserta didik membuat mereka selalu terikat untuk belajar, karena mereka harus mempresentasikan hasil belajar di hadapan pergroup dan pengajar mereka. Dengan demikian, para peserta didik akan memiliki tanggung jawab dan harus bergerak secara independen, karena dituntut terus melengkapi berbagai informasi keilmuan yang mereka butuhkan untuk dipresentasikan di depan kelas pada setiap minggu.

4. Arus masuk pendidikan tinggi yang kian besar dan kebutuhan pasar yang semakin lebar dan ragam, maka kebutuhan belajar para peserta didik juga semakin diversifikatif sesuai arah profesi yang akan mereka tuju pasca belajar di perguruan tinggi. Pembelajaran berbasis pada peserta didik memberi mereka peluang untuk mempelajari keilmuan yang ditekuninya secara independen dan tidak terikat dengan bahan ajar yang menjadi fokus kajian teman lain dari program studi yang berbeda, atau bahkan mungkin dari program studi yang sama.

Sementara itu, beberapa keuntungan belajar berdasar Audience Centered pada metode presentasi, bagi pengajar antara lain:

1. Melahirkan peran yang sangat menarik bagi pengajar, karena penyiapan bahan ajar, proses pembelajaran, dan penyimpulan, semua ditugaskan pada peserta didik, pengajar hanya melakukan konfirmasi atas bahan yang mereka kaji, termasuk kesimpulan yang mereka rumuskan. Di saat yang sama, ini merupakan kesempatan baik bagi para pengajar untuk 
memberikan tantangan bagi para peserta didiknya dalam meningkatkan kualitas proses dan hasil belajar mereka.

2. Sinergi antara pembelajaran dengan penelitian. Selain memungkinkan pengajar mengontrol tugas peserta didik sampai pada level pengetahuan tertinggi, Audience Centered pada metode presentasi memungkinkan pengajar mensinergikan kegiatan penelitiannya dengan programprogram pembelajaran (bersama peserta didik), sehingga akan terus tervalidasi oleh masukan-masukan yang dinamis.

3. Pengembangan profesional berkelanjutan. Audience Centered pada metode presentasi memungkinkan pengajar memberi tugas pada para peserta didik untuk selalu mengupdate pengetahuan mereka tentang berbagai teori dengan mengakses berbagai jurnal ilmiah terkini, sehingga pengajar akan memperoleh masukan terhadap penelitian yang sedang mereka lakukan.

\section{Peserta didik sebagai pelaku Audience Centered}

Audience Centered pada metode presentasi adalah salah satu strategi pembelajaran yang berbasis pada peserta didik (Student Centered Learning). Strategi pembelajaran ini merupakan pembelajaran yang berorientasi pada aktivitas peserta didik dan menerapkan prinsip learning by doing. Rasa ingin tahu peserta didik pada hal yang belum diketahui mendorong keterlibatannya secara aktif dalam proses pembelajaran (Pannen, 2001: 42).

Hal ini berarti bahwa sistem pembelajaran menempatkan peserta didik sebagai subyek pembelajaran yang aktif. peserta didik bukan objek pembelajaran yang dijejali dengan informasi, tetapi peserta didik adalah subyek yang memiliki potensi. Sehingga proses pembelajaran harus diarahkan untuk mengembangkan seluruh potensi yang dimiliki peserta didik. Audience Centered pada metode presentasi dapat diterapkan dalam proses pembelajaran dengan berbagai tehnik alternatif. Tehnik alternatif pembelajaran yang di aplikasikan di kelas menyesuaikan materi serta kemampuan presenter yang meng-handle presentasi. Hal ini dilakukan untuk menghindari rasa bosan audien dengan strategi pembelajaran yang monoton. Tehnik presentasi dapat berupa diskusi, game, role-play, question- 
answer, mind-map, paper ataupun peta (gambar) sesuai dengan materi serta tugas pembelajaran. Keberhasilan strategi Audience Centered pada metode presentasi ini perlu didukung dengan media serta sumber belajar yang cukup memadai, ketersediaan LCD, laptop, serta jaringan wifi yang menjangkau tiap kelas.

Pembelajaran berpusat pada peserta didik bersifat strategis dan inovatif. Strategis karena memfasilitasi siswa aktif dalam proses pembelajaran yang mengembangkan potensi dirinya, dan menempatkan peserta didik sebagai subyek yang bertanggung jawab atas proses pembelajaran. Inovatif, karena peserta didik tidak terikat oleh kelas belajar.

Pada penerapannya, Audience Centered pada metode presentasi ini berpusat pada pembagian peran peserta didik di dalam kelas; pengajar sebagai super judge yang bertugas mengawasi jalannya presentasi dan memberikan evaluasi dan penilaian akhir terhadap keberhasilan presentasi, para presenter yang meng-handle jalannya presentasi, dan peserta didik yang lain sebagai audien.

Pengajar sebagai super judge bertindak membuka kegiatan pembelajaran di kelas, menyediakan waktu sepenuhnya kepada para presenter untuk meng-handle seluruh kegiatan pembelajaran dalam bentuk presentasi dan mengawasi jalannya presentasi, serta memberikan evaluasi dan penilaian akhir atas berhasil tidaknya para presenter meng-handle jalannya presentasi. Disebut sebagai super judge karena penilaian terhadap audien telah dilakukan oleh para presenter yang meng-handle jalannya presentasi menggantikan pengajar, sedangkan penilaian akhir untuk para presenter dan audien tetap bergantung pada penilaian akhir pengajar.

Para presenter memegagang penuh kendali kegiatan pembelajaran dalam bentuk presentasi. Tehnik yang mereka pakai beragam tergantung dengan kreatifitas tiap kelompok presenter. Disini, kreatifitas dan inovasi para presenter sangat dibutuhkan dalam mencapai keberhasilan pembelajaran. Waktu penuh yang diberikan oleh pengajar kepada para presenter harus benar-benar digunakan dengan seefektif dan seefisien mungkin.

Para presenter harus mempertimbangkan beberapa hal demi keberhasilan pembelajaran melalui presentasi, diantaranya adalah: 
1. Mengambil alih peran pengajar untuk menerapkan teknik pembelajaran yang baik.

2. Aktif berbicara seperti public speaker; yakni berperan aktif dan menguasai tehnik-tehnik berbicara seperti public speaker.

3. Memilih tehnik pembelajaran yang tepat untuk diterapkan dengan mempertimbangkan karakteristik, kebutuhan, kompetensi dan motivasi audiennya.

4. Mengusai materi dengan baik melalui tehnik yang diterapkan.

5. Meng-handle jalannya presentasi dan seluruh kegiatan pembelajaran dengan baik.

6. Menguasai audien dan melibatkan mereka untuk berpartisipasi aktif didalam setiap kegiatan pembelajaran.

7. Menggunakan waktu dengan efektif dan efisien.

Peserta didik yang bukan bertugas sebagai presenter, maka mereka berperan sebagai audien. Audien sangat mempengaruhi keberhasilan kegiatan presentasi. Karena sebuah presentasi dapat dikatakan berhasil ketika audiennya berpartisipasi aktif dan senang mengikuti seluruh kegiatan pembelajaran yang diterapkan oleh para presenter. Dalam artian para presenter telah menerapkan tehnik yang tepat dengan mempertimbangkan karakteristik, kebutuhan, kompetensi dan motivasi audiennya. Audien sebagai pusat pembelajaran mempunyai pengaruh dalam penilaian pengajar sebagai super judge terhadap para presenter.

\section{Audience Centered pada Metode Presentasi; Aktualisasi \\ Pendekatan Student Centered Learning}

Meskipun tampaknya beberapa model yang dianjurkan dalam pembelajaran yang berpusat kepada siswa mengurangi dominasi pengajar di kelas, namun tetap kegiatan belajar tidak akan lepas dari kemampuan seorang pengajar memberikan pengaruh kepada audiensnya, yakni para peserta didik. Didalam konteks pembelajaran berpusat pada peserta didik ini, kemampuan pengajar untuk menjadi super judge dan para presenter sebagai speaker yang menginspirasi sangat penting untuk dipraktikkan sehingga menumbuhkan prakarsa, kreativitas, dan kemandirian peserta didik. Jika dilihat dari perspektif "an audience centered speechmaking approach", maka audiens memiliki 
posisi yang sangat penting dalam kegiatan public speaking. Begitu juga di dalam konteks pembelajaran yang berpusat pada peserta didik ini, para presenter yang mengambil bagian sebagai speaker harus menempatkan peserta didik atau audiens-nya dengan benar. Selama ini, jika penelitian menunjukkan kegagalan proses belajar mengajar di kelas (Kusuma, dkk, 2010: 4) salah satunya dikarenakan kurang mampunya seorang pengajar atau presenter menempatkan peserta didiknya sebagai audiens.

Dalam audience centered speechmaking, Beebe dan Beebe (2010: 21) mengatakan "as a public speaker, you will learn to adapt to your audience based on who your listeners are, their expectations for your speech, and their actions to what you are saying." Menurut perspektif ini, dalam konteks pembelajaran, seorang presenter harus benar-benar mengenal audiensnya, serta apa harapan mereka melalui pelajaran yang disampaikan. Lebih lanjut, Beebe dan Beebe (2010: 21) menyatakan bahwa "the audience is the most important component in the communication process". Hal ini benar jika ditinjau dari persepektif audience-centered approach.

Namun dalam praktiknya, menjadikan audiens penting dalam proses pembelajaran tidaklah mudah. Dominasi pengajar ataupun presenter dengan anggapan bahwa pengetahuannya lebih banyak dan lebih berkuasa di kelas, terkadang menegasikan argumen Beebe mengenai pentingnya peserta didik sebagai audiens. Dalam berbagai kegiatan pembelajaran atau pelatihan, acapkali pengajar, presenter, atau pelatih justru lebih menonjolkan kemampuannya dan beragam metode yang menarik tanpa mempedulikan apakah hal tersebut sesuai dengan audiens-nya. Akhirnya, seperti studi yang dilakukan oleh Rahayasa Research and Training (Kusuma, dkk., 2010: 4), proses pembelajaran yang demikian hanya menghasilkan peserta didik yang menerima pengetahuan; bukan membangun sendiri pengetahuannya secara kontekstual.

Beebe dan Beebe (2010: 21) juga mengatakan bahwa "the decoding of speaker's message depends on the reviewer's or listener's, particular blend of past experiences, attitudes, believe and value" (pengawasan dan pesan yang disampaikan oleh seorang pembicara bergantung pada pengalaman masa lalu, sikap, keyakinan dan nilai- 
nilai yang dipegang oleh pendengarnya). Di dalam proses belajar mengajar, karena pemahaman materi pengajaran sebagai pesan ditentukan oleh latar belakang pesrta didik sebagai audiens, maka pengajar atau presenter sebagai speaker perlu melakukan riset audiens untuk mengetahui karakter pesrta didik sebagai audiens.

Riset mengenai peserta didik sebagai audiens ini dapat dilakukan dalam tiga tahap. Tahap pertama, adalah melakukan riset sebelum kelas dimulai. Riset ini bisa dilakukan dengan mengamati data pesrta didik, berkaitan dengan latar belakang keluarga, suku, usia, catatan akademik, dan data lain yang didokumentasikan. Halhal yang perlu diketahui adalah keunikan dari individu-individu tertentu serta keunikan kelas secara keseluruhan. Setelah itu, dapat dibuat catatan mengenai karakter individu maupun kelas. Hal ini berguna untuk melakukan pengenalan awal mengenai siapa audiens dari presentasi yang akan dilakukan di dalam kelas.

Selain itu, diperlukan riset tahap ke dua yang disebut sebagai riset simultan. Riset audiens secara simultan ini dilakukan saat presentasi berlangsung. Saat berada di depan audiens, presenter harus melakukan pengamatan dan wawancara secara simultan. Misalnya mengadakan interview spontan terhadap audiensnya.

Tahap ke tiga yang perlu dilakukan sebagai riset audiens adalah mengevaluasi bagaimana keterikutan peseta didik di dalam kelas selama presentasi tersebut berlangsung. Hal ini dapat digunakan sebagai masukan bagi kelompok presentasi selanjutnya. Beberapa karakter penting yang harus didapat dari riset audiens ini adalah; diversitas (budaya, nilai-nilai, interest, latar belakang keluarga), level pendidikan, pengalaman individu, tren (fashion, film, dan gadget). Dengan memahami karakter kelas, audiens akan menjadi pusat yang penting untuk seorang presenter meng-handle jalannya presentasi di kelas.

\section{Simpulan}

Dari pembahasan diatas dapat ditarik kesimpulan bahwa pelaksanaan Audience Centered pada metode presentasi merupakan salah satu media yang dapat dipakai dalam mengaplikasikan pendekatan Student Centered Learning (SCL). Beberapa kegiatan 
yang dapat dipakai dalam usaha mengaktifkan siswa diantaranya seperti penugasan, memberi peluang mempresentasikan hasil kajian, berdiskusi peer group, dan menyimpulkan hasil diskusi.

Beberapa manfaat strategi audiance centered bagi peserta didik yang menjadi presenter dan yang menjadi audien antara lain: 1) Menjadikan para peserta didik sebagai bagian integral dari komunitas akademik, 2) Meningkatkan motivasi belajar peserta didik, 3) Peserta didik menjadi lebih independen dan bertanggung jawab untuk terus belajar. Sedangkan manfaat strategi Audience Centered pada metode presentasi, bagi pengajar antara lain: 1) pengajar lebih bersifat sebatas melakukan konfirmasi atas materi kajian, 2) Sinergi antara pembelajaran dengan penelitian, 3) Pengembangan profesional berkelanjutan.

Beberapa hal yang perlu dipertimbangkan sebagai seorang presenter diantaranya: 1) Mengambil alih peran pengajar untuk menerapkan teknik pembelajaran yang baik, 2) Aktif berbicara seperti public speaker; yakni berperan aktif dan menguasai tehnik-tehnik berbicara seperti public speaker, 3) Memilih tehnik pembelajaran yang tepat untuk diterapkan dengan mempertimbangkan karakteristik, kebutuhan, kompetensi dan motivasi audiennya, 4) Mengusai materi dengan baik melalui tehnik yang diterapkan, 5) Meng-handle jalannya presentasi dan seluruh kegiatan pembelajaran dengan baik, 6) Menguasai audien dan melibatkan mereka untuk berpartisipasi aktif didalam setiap kegiatan pembelajaran, 7) Menggunakan waktu dengan efektif dan efisien.

Dari hasil diatas, penulis memandang perlunya metode ini bisa diterapkan sebagai sebuah langkah untuk meminimalisir gaya belajarmengajar model passive learning melalui ceramah, membaca, audiovisual, dan demonstrasi hanya mampu menghasilkan pencapaian belajar paling tinggi $30 \%$. 


\section{DAFTAR PUSTAKA}

Attard, Angela, dkk. 2010. Student Centred Learning, Toolkit for students Staffs, and Higher Education Institution. Education International and the European Student Union, Brussel, Belgia.

Beebe, S.\& Beebe, J. 2010. Public Speaking: An Audience-Centered Approach (7thed.). USA: Pearson.

Bowman, Daria Price. 1998. Presentations. Madison WI: F+W Publications Inc.

Hamalik, Oemar. 2004. Proses Belajar Mengajar. Jakarta: Bumi Aksara.

Hamalik, Oemar. 2009. Dasar-dasar Pengembangan Kurikulum. Bandung: Remaja Rosda-karaya.

Kurdi, Fauziah Nuraini. 2009. Penerapan Student Centered Learning dari Teacher Centered Learning: Mata Ajar Ilmu Kesehatan pada Program Studi Penjaskes. Forum Kependidikan, volume 28 No. 2.

Kusuma, D., Hermana, D., Supardan, D., Undang, G. 2010. Contextual Teaching and Learning: Sebuah Panduan Awal dalam Pengembangan PBM. Yogyakarta: Rahayasa.

Pannen, Paulina dkk. 2001. Konstruktivisme Dalam Pembelajaran. Jakarta: PAU-PPAI Universitas Terbuka.

Rosyada, Dede. 2015. Student Centred Learning. Jakarta: UIN Syarif Hidayatullah.http://uinjkt.ac.id/id/student-centeredlearning-2/

Syamsul, Arifin. 2010. Memahami KBK_SCL dan implementasinya. P3AI-ITS. Diakses dari: http://www.vilila.com/2010/10/ memahami-kbk-scl-dan- implementasinya.html

Sanjaya, Wina. 2007. Strategi Pembelajaran Berorientasi Standar Proses Pendidikan. Jakarta: Kencana.

Swestin, Grace \& Primasanti, K.B. 2014. Public Speaking Dalam Konteks Pengajaran. Jurnal SCRIPTURA, Vol. 4, No. 2, Desember 2014: 60-68. 
Dliyaul Millah

Trianto. 2009. Mendesain Model Pembelajaran Inovatif Progresif. Jakarta: Kencana Prenada Media Group.

Trinova. 2013. Pembelajaran Berbasis Student Centered Learning pada Materi PAI. Jurnal Al-Ta'lim, Jilid 1, No. 4. Hlm. 324-335.

Undang-undang No.20 Tahun 2003. Sistem Pendidikan Nasional (SISDIKNAS). Jakarta: Sinar Grafika. 